Magdalena Dańko

Uniwersytet Opolski

Katedra Kultury i Języka Francuskiego

Ewa Wieszczeczyńska

Nauczycielskie Kolegium Języków Obcych we Wrocławiu

\title{
WYMOGI WSPÓŁCZESNEGO RYNKU PRACY W ODNIESIENIU DO KOMPETENCJI ABSOLWENTÓW KIERUNKÓW HUMANISTYCZNYCH
}

\section{Skills and competencies required from humanities graduates \\ in the current job market}

\begin{abstract}
This paper presents the results of a pilot study conducted in 60 selected companies located in Wrocław and Lower Silesia. The main objective of the study was to get information about prospective employers' expectations of graduates of humanities with foreign language knowledge and skills, should those companies decide to employ them. It was found that according to employers social and personal competencies are as important as skills in using specialized language and new technologies. Preferred are graduates who are fluent in two foreign languages (English and German) and who have extensive general knowledge.
\end{abstract}

\section{Wprowadzenie}

Od kilku lat szkolnictwo wyższe cechuje duże zainteresowanie dostosowaniem koncepcji kształcenia uniwersyteckiego do wymogów, jakie stawiają przed obecnymi absolwentami studiów wyższych współczesne rynki pracy. Zwraca się szczególną uwagę na to, by osoba z dyplomem uniwersyteckim przygotowana była do funkcjonowania we współczesnym świecie. Gwałtowny rozwój technologii, wzrost zapotrzebowania na wysokiej klasy specjalistów oraz 
zwiększona mobilność inwestorów, będące wynikiem obecności Polski w strukturach Unii Europejskiej powodują, iż należy skupić się w znacznym stopniu na pragmatycznych koncepcjach kształcenia na tym szczeblu edukacyjnym.

W świetle powyższych uwag warto zatem zastanowić się, jaką wiedzą i jakimi umiejętnościami powinni charakteryzować się obecni absolwenci kierunków humanistycznych ze znajomością języków obcych. Od wielu lat bowiem ci właśnie absolwenci zatrudniani są ze względu na bardzo dobrą znajomość języków obcych oraz silną motywację, niezbędną do przyuczenia do pracy na danym stanowisku w firmie (np. pracownik centrum obsługi telefonicznej, pracownik centrum obsługi klienta, doradca klienta, asystent dyrekcji, asystent managera, kadry...), w instytucjach finansowych, turystycznych, usługowych i tych związanych z produkcją oraz kulturą.

Celem niniejszego artykułu jest przedstawienie wyników badania kompetencji pracowniczych absolwentów kierunków humanistycznych, przeprowadzonego wśród 60 wybranych instytucji na terenie Wrocławia i Dolnego Śląska. W pierwszej części opracowania zostanie pokrótce omówione samo pojęcie kompetencji zawodowej i zostaną zaprezentowane różnego rodzaju czynniki mające wpływ na definiowanie ww. zjawiska oraz wybrane badania $w$ zakresie kompetencji pracowniczych absolwentów kierunków ekonomicznych. W drugiej części zawarte będą wyniki badań własnych. Dane wykazują, że kompetencjami uznawanymi przez pracodawców za kluczowe są kompetencje społeczne i osobiste oraz umiejętności w zakresie posługiwania się językiem specjalistycznym i nowymi technologiami. Preferowani są absolwenci władający dwoma językami obcymi (język angielski + język niemiecki) oraz charakteryzujący się dużą wiedzą ogólną.

\section{Pojęcie kompetencji w zakresie zarządzania zasobami ludzkimi}

Dyskusje związane z pojęciem kompetencji zainicjował w 1973 roku McClelland, amerykański psycholog społeczny. W publikacji „Testing for competence rather than intelligence" przedstawił analizę sposobu myślenia, działania i bycia jednostek odnoszących sukcesy zawodowe, w celu doskonalenia procesów rekrutacji oraz zarządzania jakością wykonywanej pracy. Boyatzis (1982) jako pierwszy zdefiniowałł i upowszechnił pojęcie kompetencji pracowniczych. Według Boyatzisa kompetencje to „zespół cech danej osoby, na który składają się charakterystyczne dla tej osoby elementy takie, jak motywacja, cechy osobowości, umiejętności, samoocena związana z funkcjonowaniem w grupie oraz wiedza, którą ta osoba sobie przyswoiła i którą się posługuje" (Boyatzis 1982 za: Whiddett i Hollyforde 2003: 13). W następ- 
stwie, kolejne definicje uzupełniają, poszerzają lub uogólniają pojęcie kompetencji. Znaczenie omawianego pojęcia zmienia się w zależności od punktu odniesienia i potrzeb organizacji. Rozwija się zarządzanie zasobami ludzkimi (ZZL) oparte na kompetencjach. W literaturze przedmiotu pojawiają się katalogi kompetencji. Składają się z nazw oraz opisów kompetencji. W organizacjach powstają portfele kompetencji (zestawy, pakiety) dla określonych zawodów, stanowisk i funkcji.

Armstrong (2011) wyodrębnia trzy typy kompetencji: behawioralne, techniczne oraz NVQ/SVQ (National Vocational Qualifications/Scottish Vocational Qualifications). Kompetencje behawioralne dotyczą „zachowań potrzebnych do uzyskania odpowiednich wyników w takich sferach, jak praca zespołowa, komunikacja, przywództwo i podejmowanie decyzji". Niekiedy nazywa się je „umiejętnościami miękkimi”. Kompetencje techniczne odnoszą się zaś do tego, „co ludzie muszą wiedzieć i być w stanie zrobić (wiedza i umiejętności), aby skutecznie odgrywać swoje role". Czasami nazywa się je „umiejętnościami twardymi” (Armstrong 2011: 190-191).

Inne podejście do pojęcia kompetencji oznaczają NVQ/SVQ i $\mathrm{MCl}$ (Management Charter Initiative), zauważają Armstrong (2011), Whidett i Hollyforde (2003). Systemy te określają kompetencje odnosząc je do wykonywanych zadań i czynności. Opisują minimalne standardy, które umożliwiają obserwację oraz ocenę oczekiwanych efektów działań. W tym świetle Whidett i Hollyforde podkreślają istnienie dwóch różnych znaczeń pojęcia kompetencji w praktyce organizacji. Kompetencje to „zdolność skutecznej realizacji określonych zadań związanych z pracą lub osiągania pożądanych, wymiernych wyników" (nawiązuje do zadań i mierzalnych efektów pracy). Kompetencje to „zdolność realizacji konkretnych wzorców zachowań” (nawiązuje do wyznaczników behawioralnych). Stąd różne sposoby definiowania kompetencji: przedstawienie kompetencji w formie opisu zadań lub oczekiwanych efektów działań; przedstawienie kompetencji w formie opisu behawioralnego (Whidett i Hollyforde 2003).

W polskiej literaturze przedmiotu, według Kossowskiej i Sołtysińskiej, „podstawą kompetencji jest wiedza rozważana na trzech poziomach: wiedzy w potocznym rozumieniu (wiedza deklaratywna - wiem co); umiejętności (wiedza proceduralna - wiem jak i potrafię); postawy (chcę i jestem gotów wykorzystać swq wiedzę)" (Kossowska i Sołtysińska 2006:14). Orlińska-Gondor twierdzi, że „ludźmi kompetentnymi są ci, którzy uzyskują oczekiwane wyniki pracy, gdyż potrafią wykorzystać swoją wiedzę, umiejętności oraz cechy osobowości, by osiągnąć cele i spełnić standardy przypisane ich rolom" (OrlińskaGondor 2006: 170-171). Bardzo szeroko i zarazem ogólnie ujmuje definicję kompetencji Rostkowski, jako „wszelkie cechy pracowników, które używane 
i rozwijane w procesie pracy prowadzą do osiągania rezultatów zgodnych ze strategicznymi zamierzeniami przedsiębiorstwa" (2004: 40). W ramach analizy systemów zarządzania kompetencjami, wśród elementów definicji kompetencji wykorzystywanych przez firmy pochodzące z krajów UE, autor wymienia: wiedzę, umiejętności, zdolności, postawy, motywacje, wartości, osobowość (Rostkowski 2004). Filipowicz (2011) zauważa, że do opisu kompetencji stosuje się również takie aspekty jak: kwalifikacje (rozumiane jako poziom wykształcenia oraz jako formalne uprawnienia do wykonywania zawodu), wiedzę (z rozgraniczeniem na ogólną i specjalistyczną), zachowania, doświadczenie, wprawę, sposoby rozumowania, style myślenia, wyobrażenia o sobie, przyjmowane role społeczne, inteligencję (poznawczą, emocjonalną...), cechy psychofizyczne, temperament, inne. Definiuje kompetencje pracownicze jako dyspozycje w zakresie wiedzy, umiejętności i postaw, które umożliwiają realizację zadań na odpowiednim poziomie (Filipowicz 2011).

Podczas gdy jedni teoretycy i specjaliści w zakresie ZZL podkreślają „nieprecyzyjny charakter pojęcia” (Król 2006: 81) czy też "chaos definicyjny” (Kosowska i Sołtysińska 2006: 12), drudzy twierdzą, że brak jednoznacznej zgody w kwestii znaczenia pojęcia kompetencji nie musi być wadą bądź ograniczeniem w praktycznym zastosowaniu tego pojęcia (Filipowicz 2004, OrlińskaGondor 2006). Wielość definicji, w ocenie Filipowicza, „wynika z pragmatycznego nastawienia, w którym ważniejsza jest skuteczność (budowanie efektywnie funkcjonującego systemu ZZL), niż modelowa konstrukcja teoretyczna" (2011:14). Zdaniem Orlińskiej-Gondor, „trudności w jednoznacznym zdefiniowaniu kompetencji nie wpływają na zmniejszenie ich użyteczności, lecz wskazują na jedną z ich najbardziej znamiennych cech - indywidualny charakter" (2006:70). Autorka zwraca uwagę na cechy charakterystyczne kompetencji:

- złożoność (sukces w działaniu, możliwy jest dzięki odpowiedniemu połączeniu ze sobą właściwych czynników);

- operacyjność i celowość (kompetencja ma sens, jeśli odnosi się do określonego działania i rozpatrywana jest przez pryzmat celu, jakiemu służy to działanie);

- sytuacyjność (kompetentny pracownik to ten, który wykazuje zdolność do adaptacji i do efektywnego działania w zmieniającym się otoczeniu);

- zmienność (na poziom kompetencji można oddziaływać i dostosowywać do potrzeb i celów organizacji);

- mierzalność (kompetencje to kategoria stopniowalna i można przypisać im różne poziomy spełnienia) (Orlińska-Gondor 2006).

Na potrzeby niniejszego badania, przyjęłyśmy wielowymiarową, w naszej ocenie, definicję kompetencji według Króla (2006: 82): „Kompetencje - to predyspozycje w zakresie wiedzy, umiejętności i postaw, zapewniające realizację zadań 
zawodowych na poziomie skutecznym i (lub) wyróżniającym, stosownie do standardów określonych przez organizację dla danego stanowiska". Autor odnosi się do człowieka, który kompetencjami dysponuje, w celu realizacji zadań w zakresie wykonywanej pracy. Działanie to zgodne jest z wymogami organizacji oraz powierzoną rolą, stanowiskiem pracy, a jego efekty są mierzalne.

\section{Ogólnoeuropejskie i krajowe badania kompetencji absolwentów wychodzących na rynek pracy}

Wymieniane $w$ literaturze przedmiotu badania kompetencji absolwentów studiów wyższych, które mają charakter ogólnoeuropejski, skupiają się na określeniu poziomu kompetencji uzyskanych i oczekiwanych od młodych osób wchodzących na rynek pracy. Badania te zostały przeprowadzone przede wszystkim w wybranych krajach Europy Zachodniej. Na podstawie danych uzyskanych w badaniach Careers after Higher Education - a European Research Survey i The Flexible Professional in the Knowledge. Research into Employment and Professional Flexibility, które to objęły 11 krajów, utworzono ranking kompetencji ogólnych i specjalistycznych. Wśród najbardziej pożądanych umiejętności dominuje praca samodzielna, szybkie zdobywanie nowej wiedzy, rozwiązywanie problemów, werbalne porozumiewanie się, formułowanie myśli zrozumiałych dla innych osób, praca pod presją, podejmowanie odpowiedzialności, praca w zespole, asertywność, stanowczość i wytrwałość.

Celem badania Tuning Educational Structures in Europe było określenie nie tylko listy kompetencji ogólnych, lecz również specjalistycznych dla grupy kierunków studiów ekonomicznych. Wyniki badania wskazują, iż zarówno dla pracodawców jak i dla absolwentów najważniejszymi kompetencjami wymaganymi od nowo zatrudnianych absolwentów są umiejętność zastosowania wiedzy w praktyce, umiejętność abstrakcyjnego myślenia, analizy i rozumienia, umiejętność identyfikacji, stawiania i rozwiązywania problemów oraz umiejętność przystosowania się i działania w nowych sytuacjach (Bielecki 2011).

Podejmowane polskie badania kompetencji absolwentów wychodzących na rynek pracy dotyczą również w dużej mierze absolwentów studiów ekonomicznych. Badania mają na celu analizę oczekiwań pracodawców w zakresie kompetencji i kwalifikacji absolwentów. Omawiają czynniki decyzyjne stosowane w procesach rekrutacji, podejmują próbę oceny kształcenia oraz określenia mocnych i słabych stron absolwentów z perspektywy pracodawcy. Badania te mają za zadanie przyczynić się do weryfikacji przez uczelnie programów studiów i metod kształcenia, w efekcie do lepszego przygotowania absolwentów do wyjścia na rynek pracy (Kurkliński i Maszybrocki 
2008; SGH, American Chamber of Commerce, Ernest \& Young 2012). Wyniki ankiet przeprowadzonych wśród pracodawców opisują pewne tendencje w procesach rekrutacji. Instytucje finansowe wskazują przede wszystkim na preferencje kryteriów związanych z umiejętnościami i kompetencjami „miękkimi” absolwentów: „pracodawcy chętniej zatrudniają absolwentów innych kierunków (nawet całkowicie oderwanych od gospodarki), licząc, że ich umiejętności miękkie (np. odpowiedzialność za realizowane zadania, otwartość na zmiany, kreatywność) zrekompensują „twarde”, a te ostatnie zostaną szybko wzmocnione przez zdobywanie wiedzy w praktyce oraz system wewnętrznych szkoleń" (Kurkliński i Maszybrocki 2008: 4). Okazuje się, że kluczowym kryterium stosowanym przez pracodawców przy podejmowaniu decyzji o zatrudnieniu absolwentów uczelni są ich kompetencje osobiste i interpersonalne. Na drugim miejscu znajduje się kryterium w postaci kompetencji intelektualnych i akademickich, a na trzecim udział w stażach i praktykach (SGH, American Chamber of Commerce, Ernest \& Young 2012).

Badanie kwalifikacji i kompetencji oczekiwanych przez pracodawców od absolwentów kształcenia zawodowego (Sienkiewicz i Gruza 2009) podkreśla również kluczowe znaczenie analizy oczekiwań kompetencyjnych pracodawców w doskonaleniu podstaw programowych w celu modernizacji kształcenia zawodowego. „Skupienie się na atrakcyjności zatrudnieniowej jako na przede wszystkim zależnej od czynników indywidualnych, zdaje się przesłaniać fakt, że jest ona funkcją zarówno strony podażowej, jak i popytowej rynku pracy", zauważają autorzy (Sienkiewicz i Gruza 2009: 14). Stąd, między innymi, zasadność prowadzenia komplementarnych badań kompetencji absolwentów oraz oczekiwań kompetencyjnych pracodawców.

Przedstawione badania mają na celu określenie niezbędnych kompetencji zawodowych absolwentów kierunków ekonomicznych. Dlatego też wydaje się być zasadnym przygotowanie badań, skupiających się na kompetencjach absolwentów innych kierunków studiów.

\section{Metodologia przeprowadzonego badania}

W terminie od listopada 2011 roku do lutego 2012 roku przeprowadzono badanie pilotażowe wśród 60 wybranych firm działających na terenie Wrocławia i Dolnego Śląska. Głównym celem badania było uzyskanie informacji dotyczących kompetencji zawodowych uznawanych za najważniejsze przez pracodawców, jeśli decydują się zatrudnić absolwentów kierunków humanistycznych ze znajomością języków obcych. Zebranie danych polegało na przeprowadzeniu wywiadów ankieterskich, które zrealizowano w postaci osobistych spotkań 
z osobami odpowiedzialnymi za politykę rekrutacyjną w danej firmie. Literatura przedmiotu podkreśla, iż szczególnie w przypadku, gdy kwestionariusz zawiera pytania otwarte, ważne są osobiste spotkania, w trakcie których ankieter będzie miał możliwość stawiania dodatkowych pytań (Babbie 2009).

Analiza zebranych danych ilościowych i jakościowych została przeprowadzona w oparciu o technikę kodowania. Jak już wspomniałyśmy, w literaturze przedmiotu kompetencjom nadaje się nazwy i opatruje się opisami, które umożliwiają prawidłowe ich rozróżnianie. Zbiór ściśle związanych ze sobą kompetencji tworzy skupisko kompetencji (Whidett i Hollyforde 2003). Do kodowania danych wykorzystano model kompetencji zawodowych Filipowicza (2004: 38), modyfikując kilka zmiennych w celu dostosowania ww. schematu do badanej grupy.

\section{KOMPETENCJE BAZOWE}

\section{Kompetencje poznawcze}

- Rozwiazywanie problemów

- Szerokie horyzonty myślenia

- Elastyczność myślenia

- Gotowość do uczenia się

- Kreatywnośc

- Myślenie analityczne i logiczne

\section{Kompetencje spoleczne \\ - Negocjowanie \\ - Relacje z przełożonymi \\ - Relacje ze współpracownikami \\ - Komunikatywność \\ - Komunikacja pisemna \\ - Prowadzenie prezentacji \\ - Wywieranie wplywu \\ - Współpraca w zespole \\ - Kultura osobista \\ - Obycie miẹdzynarodowe}

$$
\begin{aligned}
& \text { Kompetencje osobiste } \\
& \text { - Orientacja na działanie } \\
& \text { - Podejmowanie inicjatywy } \\
& \text { - Radzenie sobie ze stresem } \\
& \text { - Wytrwałość } \\
& \text { - Zaangażowanie } \\
& \text { - Efektywność } \\
& \text { - Organizacja pracy } \\
& \text { - Sumienność } \\
& \text { - Podejmowanie decyzji } \\
& \text { - Wyznaczanie priorytetów } \\
& \text { - Dążenie do rezultatów } \\
& \text { - Pewność siebie } \\
& \text { - Motywacja } \\
& \text { - Inicjatywa } \\
& \text { - Odpowiedzialność }
\end{aligned}
$$

Kompetencje zawodowe

\section{KOMPETENCJE WYKONAWCZE}

Kompetencje biznesowe
- Znajomość branży
- Diagnozowanie potrzeb klienta
- Techniki sprzedaży
- Orientacja w biznesie

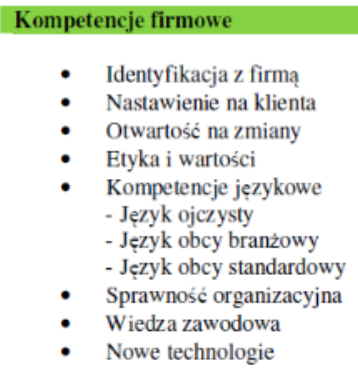

Kompetencje menedżerskie

- Budowanie zespołu

- Dbałość o podwładnych

- Delegowanie

- Motywowanie

- Odwaga kierownicza

- Przywództwo

- Organizowanie

- Planowanie

- Zarzadzanie procesami

- Zarządzanie projektami

- Myślenie strategiczne

- Zarządzanie zmiana

Schemat 1: Zmodyfikowany model kompetencji zawodowych według Filipowicza (2004: 38). 
Filipowicz wyodrębnia dwie podstawowe grupy kompetencji: kompetencje bazowe i kompetencje wykonawcze. Grupa kompetencji bazowych obejmuje skupiska kompetencji związane z jakością funkcjonowania człowieka w sferze poznawczej (elastyczność myślenia, szerokie horyzonty, rozwiązywanie problemów...), społecznej (relacje ze współpracownikami, przełożonymi, obycie międzynarodowe, negocjowanie...) i osobistej (zaangażowanie, wytrwałość, efektywność, radzenie sobie ze stresem, podejmowanie inicjatywy...). Grupa kompetencji wykonawczych obejmuje skupiska kompetencji związane z jakością funkcjonowania człowieka w zakresie podejmowanych działań, w ramach wykonywanej pracy na rzecz konkretnej organizacji: kompetencje biznesowe (orientacja w biznesie, znajomość branży...), kompetencje firmowe (identyfikacja z firmą, nastawienie na klienta...), kompetencje menedżerskie (przywództwo, budowanie zespołu, motywowanie, dbałość o podwładnych...).

\section{Analiza danych}

W pierwszej części ankiety respondenci wymienili języki obce uznawane za potrzebne do realizacji zamierzeń wynikających z działalności ich instytucji (wykres 1). Znaczna część pracodawców (50\%) wskazała, iż najbardziej ceniony jest absolwent studiów wyższych władający w sposób komunikatywny dwoma językami obcymi. Oprócz konieczności znajomości języka angielskiego wspominają najczęściej o opanowaniu języka niemieckiego, rzadziej języka francuskiego i innych języków, takich jak język rosyjski, japoński czy czeski. Podkreśla się również kompetencje w opanowaniu więcej niż dwóch języków obcych (30\%). Najczęściej wskazywana jest umiejętność w porozumiewaniu się w języku angielskim, niemieckim i francuskim. Mniejsza część (20\%) wskazała na konieczność opanowania tylko jednego języka obcego i jest nim przede wszystkim język angielski.

W dalszej części ankiety respondenci wypowiedzieli się na temat kompetencji, które uznają za najważniejsze u swoich potencjalnych kandydatów na pracowników (znających języki obce). Analiza danych, przedstawiona na wykresie 2, wykazuje, iż przeważają kompetencje bazowe (społeczne, osobiste i poznawcze), a wśród kompetencji wykonawczych najważniejszą rolę odgrywają kompetencje firmowe. W zakres tej grupy kompetencji wchodzi kompetencja językowa (język ojczysty, język obcy branżowy i język obcy standardowy) i stąd uzyskano zapewne tak wysoki wynik. 


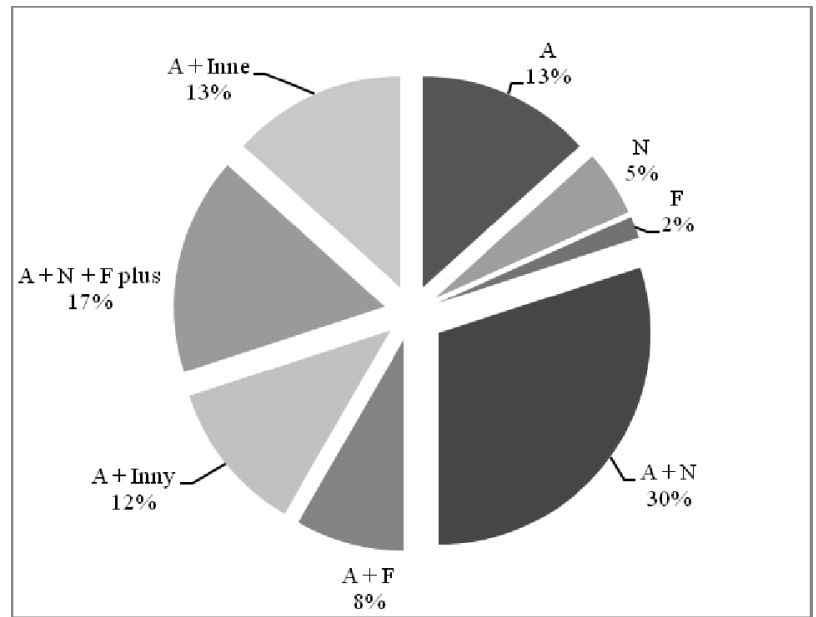

Wykres 1: Zapotrzebowanie na języki obce w firmach według pracodawców z terenu Wrocławia i Dolnego Śląska.

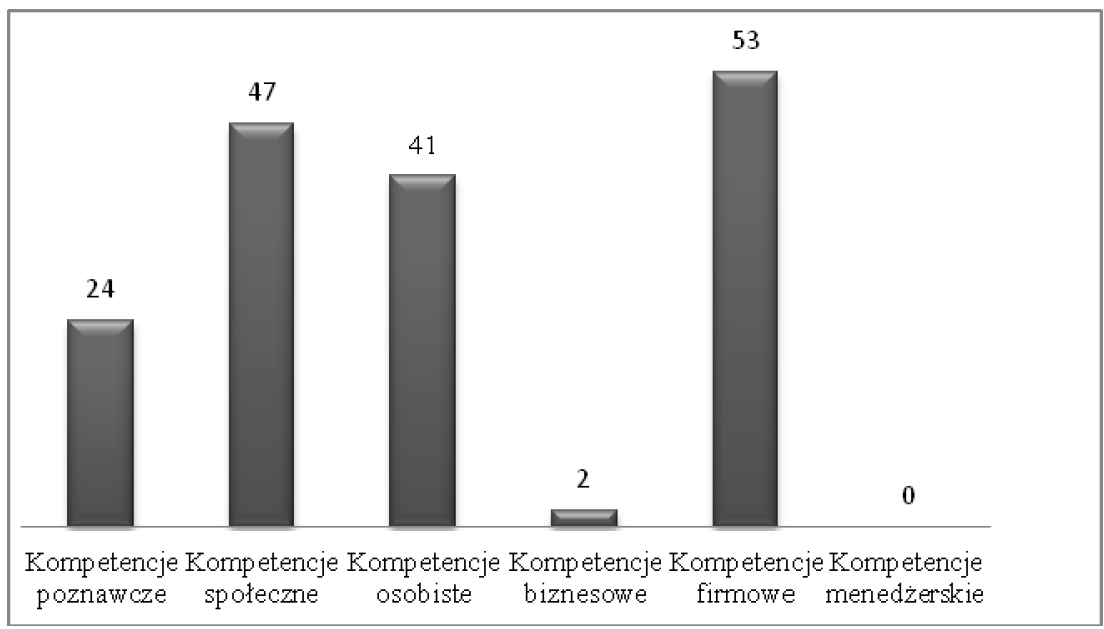

Wykres 2: Wymagane kompetencje pracownicze według pracodawców z terenu Wrocławia i Dolnego Śląska.

W oparciu o wykres 3, zauważyć można, że wśród kompetencji poznawczych zdecydowanie dominuje gotowość do uczenia się, logiczne myślenie oraz szerokie horyzonty myślenia, określane przez respondentów m.in. jako ciekawość i zainteresowanie otaczającym światem czy wiedza ogólna i obycie w świecie. Wymieniane są również kreatywność i umiejętność rozwiązywania problemów. 


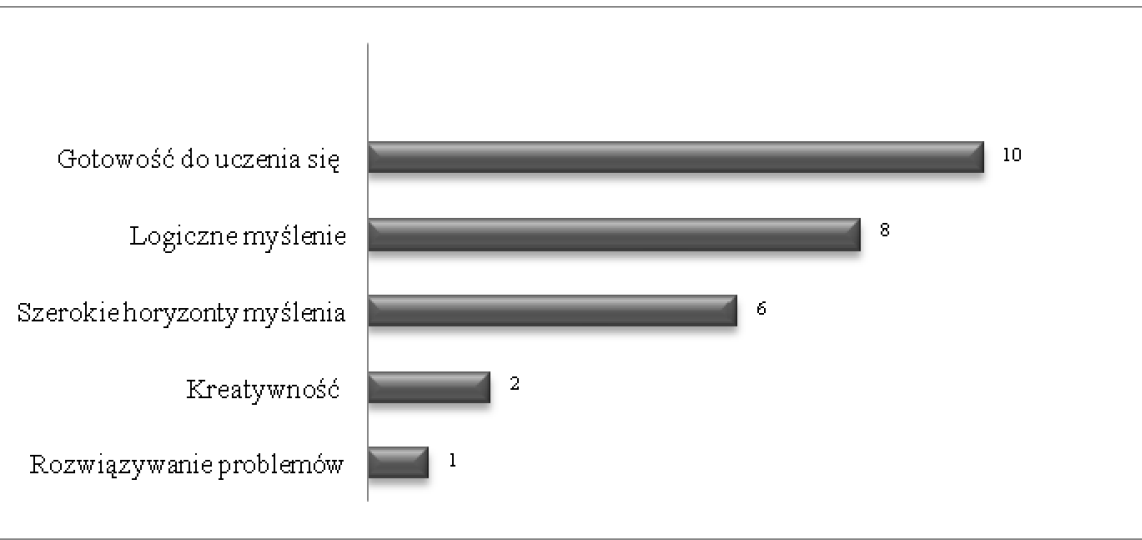

Wykres 3: Ranking ważności kompetencji poznawczych według pracodawców z terenu Wrocławia i Dolnego Śląska

Analiza danych w zakresie kompetencji społecznych podkreśla szczególną wagę komunikatywności, którą charakteryzują ankietowane osoby m.in. jako dostosowanie wypowiedzi do danego odbiorcy, umiejętne prowadzenie rozmowy, umiejętność zadawania pytań, udzielania odpowiedzi i słuchania ze zrozumieniem. Ważną rolę odgrywa również umiejętność współpracy w zespole, również tym wirtualnym oraz kultura osobista. Respondenci ponadto wysoko cenią sobie umiejętności w zakresie przejrzystego i zwięzłego prezentowania projektów, raportów i zestawień. Wymieniane są także umiejętność negocjowania, wywierania wpływu oraz obycie międzynarodowe.

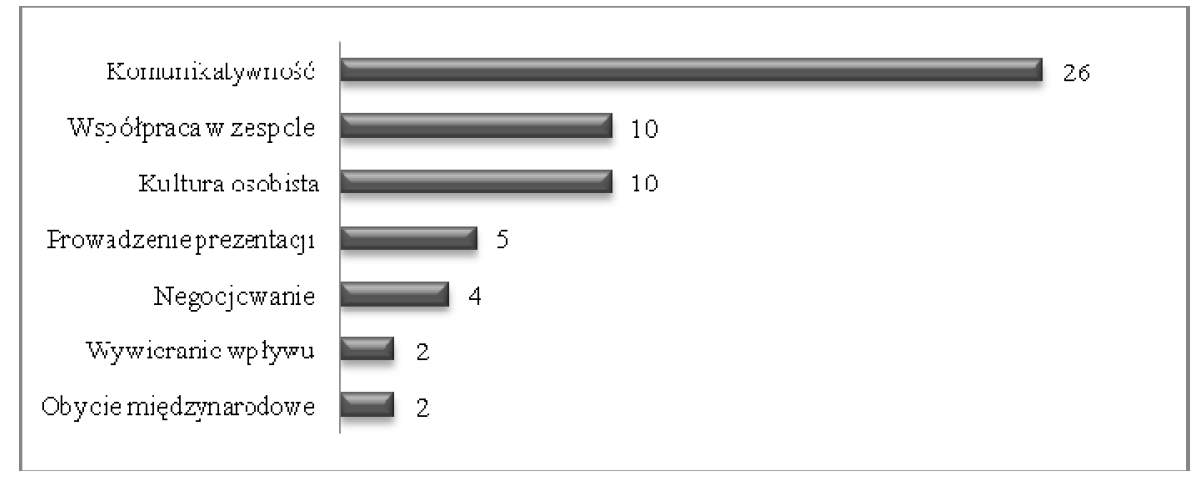

Wykres 4: Ranking ważności kompetencji społecznych według pracodawców z terenu Wrocławia i Dolnego śląska

W zakresie kompetencji osobistych respondenci przypisują wysoką rangę umiejętności organizacji pracy własnej i charakteryzują ją m.in. jako 
zmysł planowania, uporządkowanie w działaniu i systematyczność. Zwracają również szczególną uwagę na zdolność radzenia sobie w sytuacjach stresujących. Wspominają ponadto o cechach niezbędnych w osiąganiu sukcesów zawodowych, do których należą sumienność, zaangażowanie, podejmowanie inicjatywy, pewność siebie czy dążenie do zamierzonych rezultatów. Ranking ważności poszczególnych kompetencji ilustruje wykres 5.

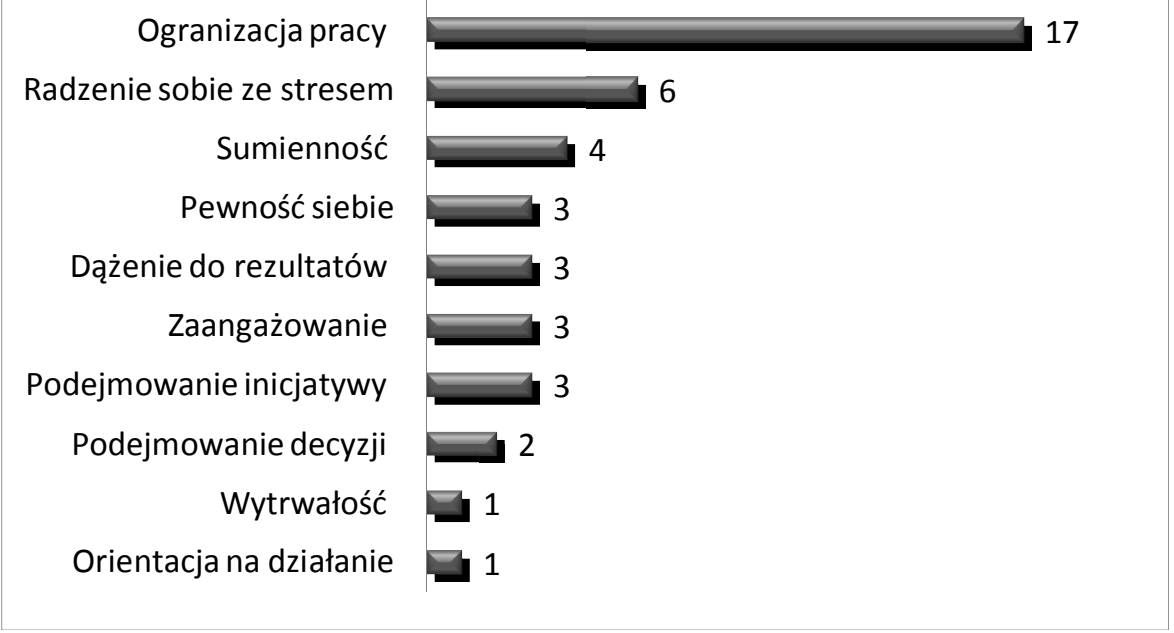

Wykres 5: Ranking ważności kompetencji osobistych według pracodawców z terenu Wrocławia i Dolnego Śląska.

Dane przedstawione na wykresie 6 pokazują, iż wśród kompetencji firmowych najwyżej ceniona jest znajomość języka obcego w zakresie skuteczności i jasności przekazu, umiejętności zadawania pytań, przygotowywania i prowadzenia prezentacji, ustnego przekazu informacji w oparciu o dokument pisany, komunikacji na odległość (tele- i wideokonferencje) oraz umiejętności adoptowania tekstów pisanych do innych potrzeb. Wskazuje się również na konieczność opanowania terminologii branżowej w języku obcym oraz znajomości typologii tekstów specjalistycznych i umiejętności ich tłumaczenia. Cenne wydają się także uwagi odnośnie kompetencji w zakresie języka ojczystego, tu ankietowane osoby wskazują m.in. na konieczność posługiwania się piękną polszczyzną w mowie i piśmie, na staranną wymowę i artykulację oraz na płynność i przejrzystość wypowiedzi. Podkreśla się również znaczenie nowych technologii w zakresie umiejętności posługiwania się nowoczesnymi programami komputerowymi, wyszukiwania informacji w sieci (konstruowanie odpowiednich zapytań w wyszukiwarkach, używanie filtrów), pracy w zespole wirtualnym, znajomości zasad bezpieczeństwa $w$ Internecie, prowadzenia tele- 
i wideokonferencji, umiejętności korzystania z instrukcji. Wymieniane są również takie kompetencje jak nastawienie na klienta, sprawność organizacyjna, otwartość na zmiany oraz identyfikacja z firmą.

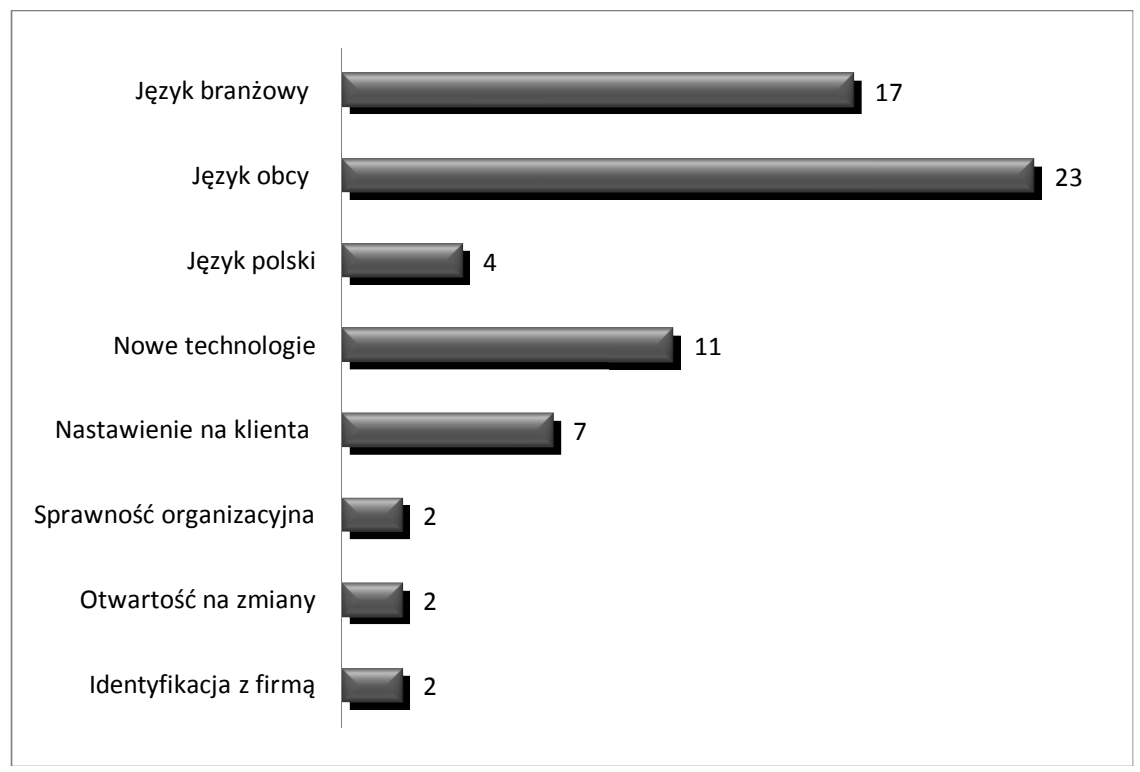

Wykres 6: Ranking ważności kompetencji firmowych według pracodawców z terenu Wrocławia i Dolnego Śląska.

Końcowe pytanie ankiety dotyczyło elementów, o które powinna zostać poszerzona oferta studiów humanistycznych, aby absolwent stał się bardziej atrakcyjny na rynku pracy. Zebrane dane w tym zakresie przedstawia wykres 7. Znaczna część respondentów podkreśla znaczenie praktyk zawodowych odbywanych w kraju i za granicą. Dzięki nim młody człowiek zyskuje obycie interkulturowe, łączy doskonalenie językowe z pracą zawodową w charakterze praktykanta i ma możliwość poznania zasad funkcjonowania przedsiębiorstwa. Ankietowane osoby uważają również, iż w kształceniu powinno się zwrócić szczególną uwagę na rozwijanie kompetencji w zakresie języka specjalistycznego i uświadamianie studentom znaczenia wiedzy ogólnej dla odpowiedniego funkcjonowania w środowisku zawodowym. Respondenci podnoszą znaczenie wiedzy historycznej, filozoficznej, z zakresu logiki, psychologii, idei religijnych czy historii doktryn oraz obycia w literaturze i elementarnej wiedzy o współczesnym świecie. Podkreślają również znaczenie szkoleń w zakresie umiejętności zarządzania projektami i tzw. umiejętności miękkich - zdaniem respondentów kompetencje społeczne nie są nadal silną stroną absolwentów studiów humanistycznych. W ankiecie wskazywane 
są także takie umiejętności jak abstrakcyjne myślenie, krytyczne myślenie, kompetencje matematyczno-numeryczne czy poprawne posługiwanie się językiem ojczystym w mowie i piśmie. Respondenci dość wysoko oceniają obycie absolwentów z nowymi mediami, choć wskazują na pewne braki w tzw. biegłym poruszaniu się w obszarze standardowych programów komputerowych i w Internecie.

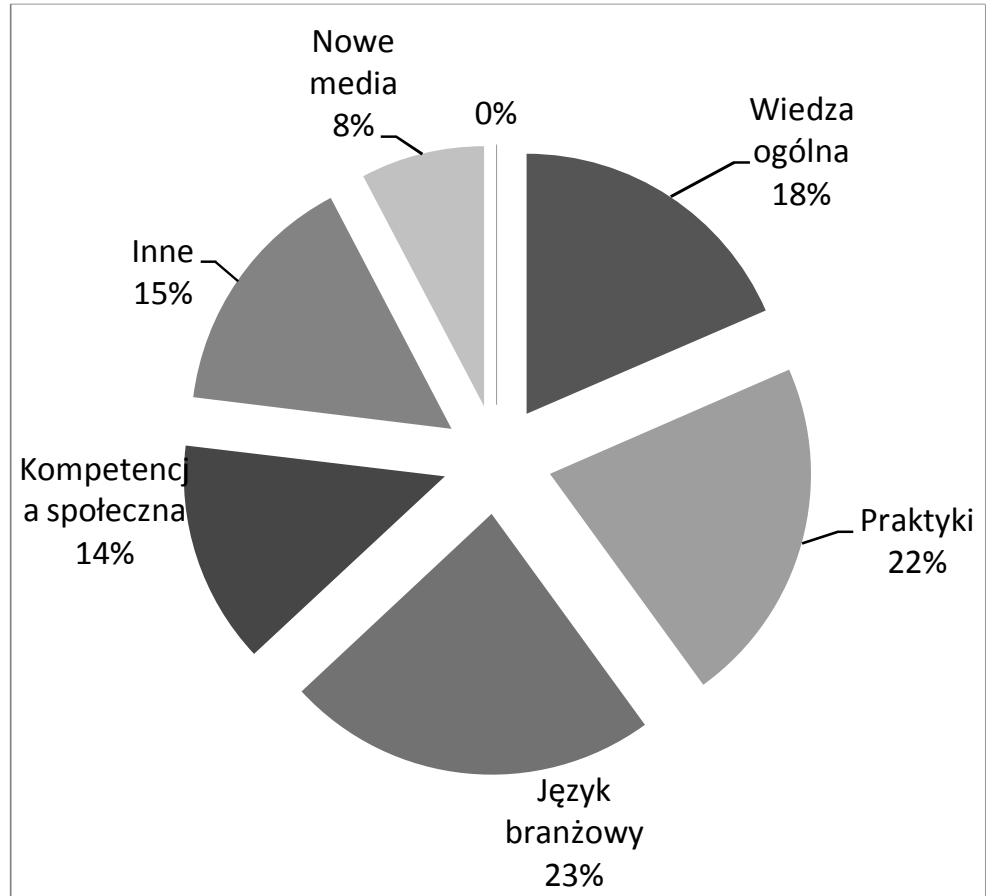

Wykres 7: Propozycje poszerzenia oferty edukacyjnej studiów humanistycznych według pracodawców z terenu Wrocławia i Dolnego Śląska.

\section{Podsumowanie}

Funkcjonowanie organizacji zatrudniających absolwentów jest zależnie, m.in. od zdolności reakcyjnej na zmieniające się czynniki zewnętrze. Zatem istotne przeobrażenia ekonomiczne, gospodarcze, prawne, demograficzne oraz społeczno-kulturowe wymagają również nowego spojrzenia na strategie kształcenia proponowane na kierunkach humanistycznych.

Mimo ograniczonego charakteru niniejszego badania, analiza popytowa rynku pracy (oparta na wymaganiach kompetencyjnych pracodawców) wskazuje na pewne tendencje w procesie rekrutacji absolwentów z zaawan- 
sowaną znajomością języków obcych (widoczne na wykresach i omówione powyżej). Kompetencje osobiste i społeczne pracowników okazują się być pewnymi stałymi wartościami, ponieważ są niezbędne do funkcjonowania w każdych warunkach. Kompetencje poznawcze umożliwiają rozwijanie i dostosowanie wiedzy i umiejętności do nowych potrzeb. Zapewne dlatego też podkreślane jest przez respondentów znaczenie wiedzy ogólnej dla odpowiednego poruszania się w środowisku zawodowym, gotowości do uczenia się czy logiczne myślenie. Kompetencje poznawcze będą niezbędne w odpowiedzi na zmieniające się firmowe wymogi kompetencyjne.

W zakresie kompetencji firmowych zauważa się duże zainteresowanie pracodawców w zakresie opanowania języka specjalistycznego. Ceniona jest również znajomość dwóch języków obcych. Może zatem warto zastanowić się nad innym charakterem studiów neofilologicznych, takich, w trakcie których studenci mieliby możliwość opanowania dwóch języków obcych na poziomie zaawansowanym. Wydaje się to być o tyle zasadne w sytuacji, gdy przeważająca część kandydatów na studia wyższe zna język angielski na poziomie co najmniej komunikatywnym.

Świadomy rozwój kompetencji osobistych, społecznych, poznawczych i firmowych, identyfikacja i doskonalenie komponentów deficytowych, zwiększy zapewne możliwości zatrudnienia młodych ludzi wchodzących na rynek pracy. W tym świetle, współpraca szkół wyższych z regionalnym rynkiem pracy wydaje się być niezbędna.

\section{BIBLIOGRAFIA}

Armstrong, M. 2011. Zarzqqdzanie zasobami ludzkimi. Warszawa: Wolters Kluwer Polska. Babbie, E. 2009. Podstawy badań społecznych. Warszawa: Wydawnictwo Naukowe PWN. Bielecki, P. 2011. « Kompetencje absolwentów studiów wyższych w świetle ogólnoeuropejskich badań CHEERS, REFLEX i TUNING ». (w) Kompetencje absolwentów studiów ekonomicznych. Perspektywa nauki i biznesu (red. K. Jędralska i J. Bernais). Katowice: Wydawnictwo Uniwersytetu Ekonomicznego: 13-66.

Filipowicz, G. 2004. Zarzqdzanie kompetencjami zawodowymi. Warszawa: Wydawnictwo PWE.

Filipowicz, G. 2011. Uniwersalny Model Kompetencyjny. Warszawa: Obserwatorium zarządzania. http://katalizatorinnowacji.pl/uploads/files/0/145/Kompetencje_book.pdf DW 31.10.2012.

Gondor-Orlińska, A. 2006. "Zarządzanie ludźmi oparte na pojęciu kompetencji ». (w) Nowe tendencje i wyzwania w zarzqdzaniu personelem (red. L. ZbiegieńMaciąg). Kraków: Wolters Kluwer Polska, Oficyna Ekonomiczna: 168-191.

Kossowska, M. i Sołtysińska, I. 2006. Szkolenia pracowników a rozwój organizacji. Kraków: Oficyna Ekonomiczna. 
Król, H. 2006. « Podstawy koncepcji zarządzania zasobami ludzkimi ». (w) Zarzq̨dzanie zasobami ludzkimi (red. H. Król i A. Ludwiczyński). Warszawa: Wydawnictwo Naukowe PWN: 50-91.

Kurkliński, L. i Maszybrocki, M. 2008. Ocena kształcenia absolwentów studiów o kierunku ekonomia oraz finanse i rachunkowość a potrzeby rekrutacyjne instytucji finansowych. Warszawa: Związek Banków Polskich, Polska Izba Ubezpieczeń. http://www.zbp.pl/photo/!files/ocena-ksztalc-fin.pdf DW 31.10.2012.

McClelland, D.C. 1973. "Testing for competence rather than intelligence ». American Psychologist 28 (1): 1-14.

Rostkowski, T. 2004. "Zarządzanie kompetencjami w UE ". (w) Standardy europejskie w zarzqdzaniu zasobami ludzkimi (red. M. Juchnowicz). Warszawa: Wydawnictwo Poltext: 39-54.

Sienkiewicz, Ł. i Gruza, M. 2009. Badanie kwalifikacji i kompetencji oczekiwanych przez pracodawców od absolwentów kształcenia zawodowego. Warszawa: Krajowy Ośrodek Wspierania Edukacji Zawodowej i Ustawicznej, GHK Consulting Ltd. pokl.koweziu.edu.pl/pliki/GHK_raport_publikacja.pdf DW 31.10.2012.

SGH, American Chamber of Commerce, Ernst\&Young. 2012. Kompetencje i kwalifikacje poszukiwane przez pracodawców wśród absolwentów szkół wyższych wchodzqcych na rynek pracy. Warszawa: SGH, American Chamber of Commerce, Ernst\&Young. http://www.sgh.waw.pl/ogolnouczelniane/bwb/rada_konsultacyjna/RKPK_ra port_2012.pdf DW 31.10.2012.

Whiddet, S. i Hollyforde, S. 2003. Modele kompetencyjne w zarzqdzaniu zasobami ludzkimi. Kraków: Oficyna Ekonomiczna. 